\title{
TINJAUAN PELAKSANAAN KARS 2012 MKI 16 BERDASARKAN SPO DI RSU IMELDA PEKERJA INDONESIA MEDAN TAHUN 2018
}

\author{
1. Ali Sabela; ${ }^{2}$. Nidiya Kartika Pulungan \\ 1. Dosen APIKES Imelda, Jalan Bilal Nomor 52 Medan; '2.Alumni APIKES Imelda
}

E-mail: ${ }^{1 .}$ alisabelahasibuan@gmail.com

\begin{abstract}
ABSTRAK
Standar MKI 16 menjelaskan bahwa dokumen rekam medis harus dilindungi dari kehilangan dan kerusakan serta akses dan penggunaan oleh yang tidak berhak. Berdasarkan survey awal diketahui dari 23. 934 dokumen rekam medis masih dijumpai $15 \%$ persentase berkas yang hilang dan rusak. Penelitian ini dilakukan untuk mengetahui pelaksanaan MKI 16 Berdasarkan SPO di Rumah Sakit Imelda Pekerja Indonesia.Metode penelitian adalah deskriptif dengan metode observasi dan lembar cheklist. Pengumpulan data melalui observasi dan lembar cheklist terhadap SPO yang ada di Rumah Sakit Umum Imelda Pekerja Indonesia.Hasil penelitian ini menunjukkan bahwa kepatuhan petugas rekam medis terhadap standar prosedur operasional (SPO) MKI 16 sudah sesuai dengan pekerjaan yang dilakukan petugas rekam medis, namum petugas masih membiarkan DRM tercecer atau berserajan di lantai ruang filling. Sebaiknya perlu dilakukan untuk kerapian penyimpanan DRM petugas rekam medis agar lebih memperhatikan kerapian DRM rekam medis.
\end{abstract}

Kata Kunci $\quad$ : MKI 16, SPO. DRM

\section{PENDAHULUAN}

Rumah Sakit merupakan bagian penting dari sistem kesehatan. Rumah Sakit menyediakan pelayanan kuratif komplek, pelayanan gawat darurat, pusat alih pengetahuan dan teknologi dan berfungsi sebagai pusat rujukan. Rumah Sakit harus senantiasa meningkatkan mutu pelayanan sesuai dengan harapan pelanggan untuk meningkatkan kepuasan pemakai jasa. Dalam Undang-Undang Nomor 44 Tahun 2009 Tentang Rumah Sakit, pasal 29 huruf b menyebutkan bahwa Rumah Sakit wajib memberikan pelayanan kesehatan yang aman, bermutu, anti diskriminasi dan efektif dengan mengutamakan kepentingan pasien sesuai dengan standar pelayanan Rumah Sakit, kemudian pada pasal 40 ayat (1) disebutkan bahwa dalam upaya peningkatan mutu pelayanan Rumah Sakit wajib dilakukan Akreditasi secara berkala minimal tiga tahun sekali. Dari UndangUndang Rumah Sakit tersebut diatas
Akreditasi Rumah Sakit penting untuk dilakukan dengan alasan agar mutu dan kualitas diintegrasikan dan dibudayakan ke dalam sistem pelayanan di Rumah Sakit (Prawira dan Asfawi,2015)

Proses Akreditasi dirancang untuk meningkatkan budaya keselamatan dan budaya kualitas di Rumah Sakit, sehingga senantiasa berusaha meningkatkan mutu dan pelayanannya. Melalui proses Akreditasi salah satu manfaatnya Rumah Sakit dapat meningkatkan kepercayaan masyarakat bahwa Rumah Sakit menitik beratkan sasarannya pada keselamatan pasien dan mutu pelayanan. Standar Akreditasi Rumah Sakit merupakan upaya Kementrian Kesehatan RI menyediakan suatu perangkat yang mendorong Rumah Sakit senantiasa meningkatkan mutu dan keamanan pelayanan. 
Dengan demikian Rumah Sakit harus menerapkan standar Akreditasi Rumah Sakit sesuai dengan penjabaran dalam standar Akreditasi Rumah Sakit edisi 2012. Sesuai dengan standar Akreditasi Rumah Sakit, sebagai bagian peningkatan kinerja, RumahSakit secara teratur melakukan penilaian terhadap DRM yang kurang diperhatikandalam aspek fisik maupun kualitas isi DRM. Rekam medis adalah berkas yang berisi catatan dan dokumen tentang identitas pasien, pemeriksaan, pengobatan, tindakan dan pelayanan lainnya yang telah diberikan kepada pasien (Permenkes,No.269/MENKES/PER/III/200 $8)$.

Pelayanan yang bermutu bukan hanya pada pelayanan medis saja, tetapi juga pada penyelenggaraan Rekam Medis yang menjadi salah satu indikator mutu pelayanan Rumah Sakit berdasarkan standar manajemen komunikasi dan informasi (MKI) 16 yang menitik beratkan pada kerusakan, kehilangan dan perlindungan terhadap Dokumen Rekam Medis pasien dan akses serta penggunaan yang tidak sah.

Akreditasi berdasarkan Standar Manajemen Komunikasi dan Informasi bertujuan untuk penilaian elemen-elemen, salah satunya standar yang terkait dengan Gangguan Rekam Medis yang dilindungi dari kerusakan dan kehilangan adalah MKI 16. Akreditasi berdasarkan Standar Manajemen Komunikasi dan Informasi bertujuan untuk penilaian elemen-elemen, salah satunya standar yang terkait dengan Gangguan Rekam Medis yang dilindungi dari kerusakan dan kehilangan adalah MKI 16, berdasarkan pemeliharaan DRM rekam medis di pengaruhi beberapa faktor, salah satunya mengenai kelembaban ruang penyimpanan sekitar $50 \%$ sampai $60 \%$ sedangkan suhu berkisar antara $18^{\circ} \mathrm{C}$ sampai $24^{\circ} \mathrm{C}$. Apabila suhu ruangan dan kelembaban tidak sesuai dengan standart yang sudah ditetapkan kemungkinan DRM yang rusak akan lebih banyak.

Berdasarkan survey awal yang dilakukan di Rumah Sakit Umum Imelda Pekerja Indonesia Medan dalam melaksanakan akreditasi mendapatkan nilai
B,artinya pelaksanaan MKI 16 sudah dianggap baik oleh Tim Akreditasi. Tetapi kenyataan masih ditemukan masalahmasalah pada penyelenggaraan rekam medis yang terkait dengan Standar MKI 16. Dengan suhu $20-22^{\circ} \mathrm{C}$ yang terbilang ideal untuk pemeliharaan DRM ternyata masih terdapat DRM yang rusak. Dari 23,934 DRM masih dijumpai beberapa DRM yang hilang dan rusak dengan persentase $15 \%$, sehingga petugas harus membuatkan DRM baru untuk pasien tersebut agar mendapatkan pelayanan. Hal tersebut tentunya akan menimbulkan dampak buruk kepada pasien, karena apabila terjadi kehilangan dan kerusakan DRM informasi pasien tidak berkesinambungan dan dapat membahayakan keselamatan pasien tersebut.

Berdasarkan permasalahan tersebut penulis tertarik untuk melakukan penelitian dengan judul " Analisis Pelaksanaan KARS 2012 MKI 16 Berdasarkan SPO Di RSU Imelda Pekerja Indonesia Medan Tahun 2018".

\section{Perumusan Masalah}

Berdasarkan latar belakang diatas, maka peneliti merumuskan masalah dalam penelitian yaitu " Bagaimana pelaksanaan standar SPO MKI 16 di RSU Imelda Pekerja Indonesia Medan ?’'

\section{Tujuan Penelitian}

Menggambarkan pelaksanaan standart SPO MKI 16 di RSU Imelda Pekerja Indonesia Medan

\section{Manfaat Penelitian}

1. Bagi Rumah Sakit

Hasil penelitian ini diharapkan dapat digunakan sebagai masukan bagi rumah sakit untuk membuat kebijakan mengenai pelaksanaan akreditasi kars 2012 MKI 16 Berdasarkan SPO.

2. Bagi Intitusi Pendidikan

Memberikan tambahan referensi untuk perpustakaan yang berguna bagi para pembaca untuk menambah pengetahuan tentang Analisis Pelaksanaan KARS 2012 MKI 16 Berdasarkan SPO.

3. Bagi peneliti selanjutnya 
Memberi tambahan referensi untuk peneliti selanjutnya yang berhubungan dengan analisis pelaksanaan akreditasi KARS 2012 MKI 16 Berdasarkan SPO.

\section{METODE}

\section{Jenis Penelitian}

Jenis Penelitian yang digunakan dalam penelitian ini secara deskriptif yaitu penelitian yang menjelaskan atau menggambarkan hasil penelitian sesuai dengan keadaan yang sebenarnya.

\section{Tempat Penelitian}

Penelitan dilakukan di RSU Imelda Pekerjaan Indonesia Medan Tahun 2018.

\section{Populasi}

Populasi adalah keseluruhan subjek penelitian(Arikunto, 2010). Populasi yang digunakan dalam penelitian ini adalah semua petugas rekam medis sebanyak 22 petugas dan DRM di Rumah Sakit Umum Imelda Pekerja Indonesia Medan.

\section{Sampel}

Sampel adalah sebagian atau wakil popolasi yang diteliti(Arikunto,2010). Sampel yang digunakan dalam penelitian ini adalah seluruh populsi dijadikan sampel, yaitu 22 orang petugas dan dokumen rekam medis.

\section{Teknik Sampling}

Teknik pengambilan sampel dalam penelitian ini adalah total sampling. Total sampling adalah teknik pengambilan sampel dimana jumlah sampel sama dengan populasi (Sugiyono 2007).

\section{Teknik Pengumpulan Data}

Peneliti membuat pengumpulan data menggunakan observasi atau pengamatan yaitu melakukan pengamatan atau observasi langsung terhadap subjek peneliti (Saryono, 2013). Metode pengumpulan data untuk penelitian ini dengan cara melakukan observasi terhadap SPO yang Mendukung MKI 16 dan observasi DRM untuk mengetahui jumlah kehilangan.

\section{Variabel \\ 1. MKI 16 \\ 2. SPO MKI 16}

\section{Defenisi Operasional}

Defenisi Operasional adalah untuk membatasi ruang lingkup atau pengertian variable - variable diamati/diteliti yang bermanfaat untuk mengarahkan kepada pengukuran atau pengamatan terhadap variabel - variabel yang bersangkutasn serta pengembangan instrumen (alat ukur) (Notoatmodjo, 2012).

1. MKI yaitu Hasil pengamatan/ observasi terhadap DRM yang dilindungi dari kerusakan, kehilangan dan akses dari kebijakan RS.

2. SPO yaitu Hasil pengamatan dari SPO MKI 16.

\section{Instrumen}

Instrumen yang digunakan dalam penelitian adalah dengan menggunakan Pedoman Observasi. Pedoman Observasi digunakan untuk mengamati secara langsung pekerjaan yang dilakukan oleh petugas dalam melaksanakan Standar Akreditasi MKI 16 dalam bentuk checklist terkait dengan SPO yang mendukung pelaksanaan Standar Akreditasi MKI 16.

\section{Cara Pengumpulan Data}

a. Data Primer

Sumber data penelitian yang diperoleh secara langsung dari sumber aslinya yang berupa hasil observasi dari suatu obyek.

b. Data Sekunder

Sumber data penelitian yang diperoleh melalui media perantara atau secara tidak langsung yang berupa buku, catatan, bukti yang telah ada atau arsip baik yang dipublikasikan maupun tidak dipublikasikan.

c. Data Tersier

Suatu kumpulan dan kompilasi sumber primer dan sumber sekunder. 
HASIL

Karakteristik Informan

Tabel 1. Karakteristik Informan

\begin{tabular}{ccc}
\hline Nama & Umur & Pendidikan \\
\hline 1 & 25 & DIII RMIK \\
\hline 2 & 40 & SKM \\
\hline 3 & 30 & DIII RMIK \\
\hline 4 & 25 & DIII RMIK \\
\hline 5 & 25 & DIII RMIK \\
\hline 6 & 26 & S.Kom \\
\hline 7 & 23 & DIII Kom \\
\hline 8 & 24 & DIII Kom \\
\hline
\end{tabular}

\begin{tabular}{ccc}
\hline 9 & 23 & DIII Kom \\
\hline 10 & 23 & DIII Kom \\
\hline 11 & 24 & DIII Kom \\
\hline 12 & 24 & SKM \\
\hline 13 & 33 & SKM \\
\hline 14 & 25 & DIII RMIK \\
\hline 15 & 26 & DIII RMIK \\
\hline 16 & 25 & DIII RMIK \\
\hline 17 & 25 & DIII RMIK \\
\hline 18 & 32 & DIII RMIK \\
\hline 19 & 26 & S.RMIK \\
\hline 20 & 23 & S.RMIK \\
\hline 21 & 30 & Amd.Kep \\
\hline 22 & 25 & Amd.Kep \\
\hline
\end{tabular}

Tabel 2. Hasil Observasi Petugas Terhadap Pelaksanaan SPO MKI 16 Perlindungan Rekam Medis Dari Kehilangan Dan Kerusakan

\begin{tabular}{|c|c|c|c|}
\hline Nama & Prosedur & Ya & Tidak \\
\hline 1 & $\begin{array}{l}\text { 1.Tidak dibenarkan menyimpan rekam medis pasien } \\
\text { 2. Keterlambatan pengambilan RM yang telah selesai digunakan untuk pelayanan } \\
\text { akan di ambil oleh staf instalasi Rekam Medik } \\
\text { 3. pengembalian Berkas RM rawat inap 1x } 24 \text { Jam } \\
\text { 4. Ketidaktepatan Pengembalian RM menjadi tanggung jawab rawat inap terkait }\end{array}$ & $\sqrt{ }$ & \\
\hline 2 & $\begin{array}{l}\text { 1.Tidak dibenarkan menyimpan rekam medis pasien } \\
\text { 2. Keterlambatan pengambilan RM yang telah selesai digunakan untuk pelayanan } \\
\text { akan di ambil oleh staf instalasi Rekam Medik } \\
\text { 3. Pengembalian Berkas RM rawat inap 1x } 24 \text { Jam } \\
\text { 4. Ketidaktepatan Pengembalian RM menjadi tanggung jawab rawat inap terkait }\end{array}$ & $\sqrt{ }$ & \\
\hline 3 & $\begin{array}{l}\text { 1.Tidak dibenarkan menyimpan rekam medis pasien } \\
\text { 2. Keterlambatan pengambilan RM yang telah selesai digunakan untuk pelayanan } \\
\text { akan di ambil oleh staf instalasi Rekam Medik } \\
\text { 3. Pengembalian Berkas RM rawat inap 1x } 24 \text { Jam } \\
\text { 4. Ketidaktepatan Pengembalian RM menjadi tanggung jawab rawat inap terkait }\end{array}$ & $\sqrt{ }$ & \\
\hline 4 & $\begin{array}{l}\text { 1.Tidak dibenarkan menyimpan rekam medis pasien } \\
\text { 2. Keterlambatan pengambilan RM yang telah selesai digunakan untuk pelayanan } \\
\text { akan di ambil oleh staf instalasi Rekam Medik } \\
\text { 3. Pengembalian Berkas RM rawat inap } 1 \times 24 \text { Jam } \\
\text { 4. Ketidaktepatan Pengembalian RM menjadi tanggung jawab rawat inap terkait }\end{array}$ & $\sqrt{ }$ & \\
\hline 5 & $\begin{array}{l}\text { 1.Tidak dibenarkan menyimpan rekam medis pasien } \\
\text { 2. Keterlambatan pengambilan RM yang telah selesai digunakan untuk pelayanan } \\
\text { akan di ambil oleh staf instalasi Rekam Medik } \\
\text { 3. Pengembalian Berkas RM rawat inap } 1 \times 24 \text { Jam } \\
\text { 4. Ketidaktepatan Pengembalian RM menjadi tanggung jawab rawat inap terkait }\end{array}$ & $\sqrt{ }$ & \\
\hline 6 & $\begin{array}{l}\text { 1.Tidak dibenarkan menyimpan rekam medis pasien } \\
\text { 2. Keterlambatan pengambilan RM yang telah selesai digunakan untuk pelayanan } \\
\text { akan di ambil oleh staf instalasi Rekam Medik } \\
\text { 3. Pengembalian Berkas RM rawat inap 1x24 Jam } \\
\text { 4. Ketidaktepatan Pengembalian RM menjadi tanggung jawab rawat inap terkait }\end{array}$ & & $\sqrt{ }$ \\
\hline 7 & $\begin{array}{l}\text { 1.Tidak dibenarkan menyimpan rekam medis pasien } \\
\text { 2. Keterlambatan pengambilan RM yang telah selesai digunakan untuk pelayanan } \\
\text { akan di ambil oleh staf instalasi Rekam Medik } \\
\text { 3. Pengembalian Berkas RM rawat inap 1x24 Jam } \\
\text { 4. Ketidaktepatan Pengembalian RM menjadi tanggung jawab rawat inap terkait }\end{array}$ & & $\sqrt{ }$ \\
\hline 8 & $\begin{array}{l}\text { 1.Tidak dibenarkan menyimpan rekam medis pasien } \\
\text { 2. Keterlambatan pengambilan RM yang telah selesai digunakan untuk pelayanan } \\
\text { akan di ambil oleh staf instalasi Rekam Medik }\end{array}$ & & $\sqrt{ }$ \\
\hline
\end{tabular}


3. Pengembalian Berkas RM rawat inap 1x24 Jam

4. Ketidaktepatan Pengembalian RM menjadi tanggung jawab rawat inap terkait

9 1.Tidak dibenarkan menyimpan rekam medis pasien

2. Keterlambatan pengambilan RM yang telah selesai digunakan untuk pelayanan akan di ambil oleh staf instalasi Rekam Medik

3. Pengembalian Berkas RM rawat inap 1x24 Jam

4. Ketidaktepatan Pengembalian RM menjadi tanggung jawab rawat inap terkait.

10 1.Tidak dibenarkan menyimpan rekam medis pasien

2. Keterlambatan pengambilan RM yang telah selesai digunakan untuk pelayanan akan di ambil oleh staf instalasi Rekam Medik

3. Pengembalian Berkas RM rawat inap 1x24 Jam

4. Ketidaktepatan Pengembalian RM menjadi tanggung jawab rawat inap terkait

11 1.Tidak dibenarkan menyimpan rekam medis pasien

2. Keterlambatan pengambilan RM yang telah selesai digunakan untuk pelayanan akan di ambil oleh staf instalasi Rekam Medik

3. Pengembalian Berkas RM rawat inap 1x24 Jam

4. Ketidaktepatan Pengembalian RM menjadi tanggung jawab rawat inap terkait

12 1.Tidak dibenarkan menyimpan rekam medis pasien

2. Keterlambatan pengambilan RM yang telah selesai digunakan untuk pelayanan akan di ambil oleh staf instalasi Rekam Medik

3. Pengembalian Berkas RM rawat inap 1x24 Jam

4. Ketidaktepatan Pengembalian RM menjadi tanggung jawab rawat inap terkait.

13 1.Tidak dibenarkan menyimpan rekam medis pasien

2. Keterlambatan pengambilan RM yang telah selesai digunakan untuk pelayanan akan di ambil oleh staf instalasi Rekam Medik

3. Pengembalian Berkas RM rawat inap 1x24 Jam

4. Ketidaktepatan Pengembalian RM menjadi tanggung jawab rawat inap terkait

14 1.Tidak dibenarkan menyimpan rekam medis pasien

2. Keterlambatan pengambilan RM yang telah selesai digunakan untuk pelayanan akan di ambil oleh staf instalasi Rekam Medik

3. Pengembalian Berkas RM rawat inap 1x24 Jam

4. Ketidaktepatan Pengembalian RM menjadi tanggung jawab rawat inap terkait

15 1.Tidak dibenarkan menyimpan rekam medis pasien

2. Keterlambatan pengambilan RM yang telah selesai digunakan untuk pelayanan akan di ambil oleh staf instalasi Rekam Medik

3. Pengembalian Berkas RM rawat inap 1x24 Jam

4. Ketidaktepatan Pengembalian RM menjadi tanggung jawab rawat inap terkait

16 1.Tidak dibenarkan menyimpan rekam medis pasien

2. Keterlambatan pengambilan RM yang telah selesai digunakan untuk pelayanan akan di ambil oleh staf instalasi Rekam Medik

3. Pengembalian Berkas RM rawat inap 1x24 Jam

4. Ketidaktepatan Pengembalian RM menjadi tanggung jawab rawat inap terkait

17 1.Tidak dibenarkan menyimpan rekam medis pasien

2. Keterlambatan pengambilan RM yang telah selesai digunakan untuk pelayanan akan di ambil oleh staf instalasi Rekam Medik

3. Pengembalian Berkas RM rawat inap 1x24 Jam

4. Ketidaktepatan Pengembalian RM menjadi tanggung jawab rawat inap terkait

18 1.Tidak dibenarkan menyimpan rekam medis pasien

2. Keterlambatan pengambilan RM yang telah selesai digunakan untuk pelayanan akan di ambil oleh staf instalasi Rekam Medik

3. Pengembalian Berkas RM rawat inap 1x24 Jam

4. Ketidaktepatan Pengembalian RM menjadi tanggung jawab rawat inap terkait

19 1.Tidak dibenarkan menyimpan rekam medis pasien

2. Keterlambatan pengambilan RM yang telah selesai digunakan untuk pelayanan akan di ambil oleh staf instalasi Rekam Medik

3. Pengembalian Berkas RM rawat inap 1x24 Jam

4. Ketidaktepatan Pengembalian RM menjadi tanggung jawab rawat inap terkait 
20 1.Tidak dibenarkan menyimpan rekam medis pasien $\sqrt{ }$

2. Keterlambatan pengambilan RM yang telah selesai digunakan untuk pelayanan akan di ambil oleh staf instalasi Rekam Medik

3. Pengembalian Berkas RM rawat inap 1x24 Jam

4. Ketidaktepatan Pengembalian RM menjadi tanggung jawab rawat inap terkait

21 1.Tidak dibenarkan menyimpan rekam medis pasien

2. Keterlambatan pengambilan RM yang telah selesai digunakan untuk pelayanan akan di ambil oleh staf instalasi Rekam Medik

3. Pengembalian Berkas RM rawat inap 1x24 Jam

4. Ketidaktepatan Pengembalian RM menjadi tanggung jawab rawat inap terkait

22 1.Tidak dibenarkan menyimpan rekam medis pasien

2. Keterlambatan pengambilan RM yang telah selesai digunakan untuk pelayanan akan di ambil oleh staf instalasi Rekam Medik

3. Pengembalian Berkas RM rawat inap 1x24 Jam

4. Ketidaktepatan Pengembalian RM menjadi tanggung jawab rawat inap terkait

Tabel 3. Hasil Observasi Pelaksanaan KARS 2012 MKI 16 SPO Peminjaman Dokumen Rekam Medis

\begin{tabular}{|c|c|c|c|}
\hline Nama & Prosedur & Ya & Tidak \\
\hline 1 & $\begin{array}{l}\text { 1.Pihak peminjam harus mengisi formulir peminjamanan dengan mengisi } \\
\text { nama pasien, nomor rekam medis, dan nama peminjam, tanggal peminjaman } \\
\text { rekam medis dan diketahui kepala instalasi rekam medis } \\
\text { 2.Berkas rekam medis yang akan di pinjam harus membawa tanda bukti } \\
\text { seperti surat pengantar }\end{array}$ & $\sqrt{ }$ & \\
\hline 2 & $\begin{array}{l}\text { 1.Pihak peminjam harus mengisi formulir peminjamanan dengan mengisi } \\
\text { nama pasien, nomor rekam medis, dan nama peminjam, tanggal peminjaman } \\
\text { rekam medis dan diketahui kepala instalasi rekam medis } \\
\text { 2.Berkas rekam medis yang akan di pinjam harus membawa tanda bukti } \\
\text { seperti surat pengantar }\end{array}$ & $\sqrt{ }$ & \\
\hline 3 & $\begin{array}{l}\text { 1.Pihak peminjam harus mengisi formulir peminjamanan dengan mengisi } \\
\text { nama pasien, nomor rekam medis, dan nama peminjam, tanggal peminjaman } \\
\text { rekam medis dan diketahui kepala instalasi rekam medis } \\
\text { 2.Berkas rekam medis yang akan di pinjam harus membawa tanda bukti } \\
\text { seperti surat pengantar }\end{array}$ & $\sqrt{ }$ & \\
\hline 4 & $\begin{array}{l}\text { 1.Pihak peminjam harus mengisi formulir peminjamanan dengan mengisi } \\
\text { nama pasien, nomor rekam medis, dan nama peminjam, tanggal peminjaman } \\
\text { rekam medis dan diketahui kepala instalasi rekam medis } \\
\text { 2.Berkas rekam medis yang akan di pinjam harus membawa tanda bukti } \\
\text { seperti surat pengantar }\end{array}$ & $\sqrt{ }$ & \\
\hline 5 & $\begin{array}{l}\text { 1.Pihak peminjam harus mengisi formulir peminjamanan dengan mengisi } \\
\text { nama pasien, nomor rekam medis, dan nama peminjam, tanggal peminjaman } \\
\text { rekam medis dan diketahui kepala instalasi rekam medis } \\
\text { 2.Berkas rekam medis yang akan di pinjam harus membawa tanda bukti } \\
\text { seperti surat pengantar }\end{array}$ & $\sqrt{ }$ & \\
\hline 6 & $\begin{array}{l}\text { 1.Pihak peminjam harus mengisi formulir peminjamanan dengan mengisi } \\
\text { nama pasien, nomor rekam medis, dan nama peminjam, tanggal peminjaman } \\
\text { rekam medis dan diketahui kepala instalasi rekam medis } \\
\text { 2.Berkas rekam medis yang akan di pinjam harus membawa tanda bukti } \\
\text { seperti surat pengantar }\end{array}$ & $\sqrt{ }$ & \\
\hline 7 & $\begin{array}{l}\text { 1.Pihak peminjam harus mengisi formulir peminjamanan dengan mengisi } \\
\text { nama pasien, nomor rekam medis, dan nama peminjam, tanggal peminjaman } \\
\text { rekam medis dan diketahui kepala instalasi rekam medis } \\
\text { 2.Berkas rekam medis yang akan di pinjam harus membawa tanda bukti } \\
\text { seperti surat pengantar }\end{array}$ & $\sqrt{ }$ & \\
\hline 8 & $\begin{array}{l}\text { 1.Pihak peminjam harus mengisi formulir peminjamanan dengan mengisi } \\
\text { nama pasien, nomor rekam medis, dan nama peminjam, tanggal peminjaman }\end{array}$ & $\sqrt{ }$ & \\
\hline
\end{tabular}


rekam medis dan diketahui kepala instalasi rekam medis

2.Berkas rekam medis yang akan di pinjam harus membawa tanda bukti seperti surat pengantar

9 1.Pihak peminjam harus mengisi formulir peminjamanan dengan mengisi nama pasien, nomor rekam medis, dan nama peminjam, tanggal peminjaman rekam medis dan diketahui kepala instalasi rekam medis

2.Berkas rekam medis yang akan di pinjam harus membawa tanda bukti seperti surat pengantar

10 1.Pihak peminjam harus mengisi formulir peminjamanan dengan mengisi nama pasien, nomor rekam medis, dan nama peminjam, tanggal peminjaman rekam medis dan diketahui kepala instalasi rekam medis

2.Berkas rekam medis yang akan di pinjam harus membawa tanda bukti seperti surat pengantar

11 1.Pihak peminjam harus mengisi formulir peminjamanan dengan mengisi nama pasien, nomor rekam medis, dan nama peminjam, tanggal peminjaman rekam medis dan diketahui kepala instalasi rekam medis 2.Berkas rekam medis yang akan di pinjam harus membawa tanda bukti seperti surat pengantar

12 1.Pihak peminjam harus mengisi formulir peminjamanan dengan mengisi nama pasien, nomor rekam medis, dan nama peminjam, tanggal peminjaman rekam medis dan diketahui kepala instalasi rekam medis 2.Berkas rekam medis yang akan di pinjam harus membawa tanda bukti seperti surat pengantar

13 1.Pihak peminjam harus mengisi formulir peminjamanan dengan mengisi nama pasien, nomor rekam medis, dan nama peminjam, tanggal peminjaman rekam medis dan diketahui kepala instalasi rekam medis 2.Berkas rekam medis yang akan di pinjam harus membawa tanda bukti seperti surat pengantar

14 1.Pihak peminjam harus mengisi formulir peminjamanan dengan mengisi nama pasien, nomor rekam medis, dan nama peminjam, tanggal peminjaman rekam medis dan diketahui kepala instalasi rekam medis 2.Berkas rekam medis yang akan di pinjam harus membawa tanda bukti seperti surat pengantar

15 1.Pihak peminjam harus mengisi formulir peminjamanan dengan mengisi nama pasien, nomor rekam medis, dan nama peminjam, tanggal peminjaman rekam medis dan diketahui kepala instalasi rekam medis 2.Berkas rekam medis yang akan di pinjam harus membawa tanda bukti seperti surat pengantar

16 1.Pihak peminjam harus mengisi formulir peminjamanan dengan mengisi nama pasien, nomor rekam medis, dan nama peminjam, tanggal peminjaman rekam medis dan diketahui kepala instalasi rekam medis 2.Berkas rekam medis yang akan di pinjam harus membawa tanda bukti seperti surat pengantar

17 1.Pihak peminjam harus mengisi formulir peminjamanan dengan mengisi nama pasien, nomor rekam medis, dan nama peminjam, tanggal peminjaman rekam medis dan diketahui kepala instalasi rekam medis 2.Berkas rekam medis yang akan di pinjam harus membawa tanda bukti seperti surat pengantar

18 1.Pihak peminjam harus mengisi formulir peminjamanan dengan mengisi nama pasien, nomor rekam medis, dan nama peminjam, tanggal peminjaman rekam medis dan diketahui kepala instalasi rekam medis 2.Berkas rekam medis yang akan di pinjam harus membawa tanda bukti seperti surat pengantar

19 1.Pihak peminjam harus mengisi formulir peminjamanan dengan mengisi nama pasien, nomor rekam medis, dan nama peminjam, tanggal peminjaman rekam medis dan diketahui kepala instalasi rekam medis 2.Berkas rekam medis yang akan di pinjam harus membawa tanda bukti 


\begin{tabular}{|c|c|c|}
\hline & seperti surat pengantar & \\
\hline 20 & $\begin{array}{l}\text { 1.Pihak peminjam harus mengisi formulir peminjamanan dengan mengisi } \\
\text { nama pasien, nomor rekam medis, dan nama peminjam, tanggal peminjaman } \\
\text { rekam medis dan diketahui kepala instalasi rekam medis } \\
\text { 2.Berkas rekam medis yang akan di pinjam harus membawa tanda bukti } \\
\text { seperti surat pengantar }\end{array}$ & $\sqrt{ }$ \\
\hline 21 & $\begin{array}{l}\text { 1.Pihak peminjam harus mengisi formulir peminjamanan dengan mengisi } \\
\text { nama pasien, nomor rekam medis, dan nama peminjam, tanggal peminjaman } \\
\text { rekam medis dan diketahui kepala instalasi rekam medis } \\
\text { 2.Berkas rekam medis yang akan di pinjam harus membawa tanda bukti } \\
\text { seperti surat pengantar }\end{array}$ & $\sqrt{ }$ \\
\hline 22 & $\begin{array}{l}\text { 1.Pihak peminjam harus mengisi formulir peminjamanan dengan mengisi } \\
\text { nama pasien, nomor rekam medis, dan nama peminjam, tanggal peminjaman } \\
\text { rekam medis dan diketahui kepala instalasi rekam medis } \\
\text { 2.Berkas rekam medis yang akan di pinjam harus membawa tanda bukti } \\
\text { seperti surat pengantar }\end{array}$ & $\sqrt{ }$ \\
\hline
\end{tabular}

\section{PEMBAHASAN}

\section{Pelaksanaan MKI 16 berdasarkan SPO}

Perencanaan adalah sebuah proses yang dimulai dengan merumuskan tujuan, menyusun dan menetapkan rangkaian kegiatan untuk mencapainya (Syafrudin, 2009). Perencanaan pada hakikatnya menyusun konsep dan kegiatan yang akan dilaksanakan untuk mencapai tujuan seperti dalam pembuatan SOP (Standar Operating Procedure).

Hasil penelitian menunjukkan bahwa dalam pelaksanaan SPO perlindungan rekam medis dari kehilangan dan kerusakan terdapat 4 petugas rekam medis yang belum melaksanakan SPO dengan baik, dan 17 petugas rekam medis yang sudah menjalankan SPO dengan baik. Dalam pelaksanaan SPO peminjaman dokumen rekam medis semua petugas rekam medis berjumlah 22 orang sudah melaksanakan peminjaman sesuai dengan SPO yang ada di RSU Imelda Pekerja Indonesia.

Berdasarkan Peraturan Menteri Kesehatan Republik Indonesia Nomor 512/Menkes/PER/IV/2007 Tentang Izin Praktik dan Pelaksanaan Praktik Kedokteran BAB I pasal 1 ayat 10 Standar Prosedur Operasional adalah suatu perangkat instruksi/langkah-langkah yang dibakukan untuk menyelesaikan suatu proses kerja rutin tertentu, dimana Standar Prosedur Operasional memberikan langkah yang benar dan terbaik berdasarkan konsensus bersama untuk melaksanakan berbagai kegiatan dan fungsi pelayanan yang dibuat oleh sarana pelayanan kesehatan berdasarkan standar profesi.

\section{KESIMPULAN}

Dalam pelaksanaan standar akreditasi KARS 2012 MKI 16 berdasarkan SPO di RSU Imelda Pekerja Indonesia Medan, dalam pelaksanaan SPO perlindungan rekam medis dari kehilangan dan kerusakan terdapat 4 petugas rekam medis yang belum melaksanakan SPO dengan baik, dan 17 petugas rekam medis yang sudah menjalankan SPO dengan baik. Dalam pelaksanaan SPO peminjaman dokumen rekam medis semua petugas rekam medis berjumlah 22 orang sudah melaksanakan peminjaman sesuai dengan SPO yang ada di RSU Imelda Pekerja Indonesia.

\section{SARAN}

Berdasarkan kesimpulan diatas, disarankan kepada petugas rekam medis yang belum menjalankan pekerjaan seuai SPO agar menjalankan sesuai dengan SPO yang telah ditetapkan oleh RSU Imelda Pekerja Indonesia Medan.

\section{DAFTAR PUSTAKA}

Dirjen Yanmed. (2006). Tentang Pengolahan Data Rekam Medis.

Hatta, Gemala. (2014). Pedoman Manajemen Informasi Kesehatan di 
Sarana Pelayanan Kesehatan. Jakarta: UI - Press.

Kementerian Kesehatan RI. (2008).

Peraturan Mentri Kesehatan RI No.269

Tahun 2008.Tentang Rekam Medis.

Jakarta: Kemenkes RI.

Kementerian Kesehatan RI. (2012).

Peraturan Mentri Kesehatan RI No.012

Tahun 2012 Tentang Akreditasi Rumah

Sakit. Jakarta: Kemenkes RI.

Kementrian Kesehatan RI. (2014).

Peraturan Mentri Kesehatan RI No. 56

Tahun 2014. Klasifikasi dan Perizinan

Rumah Sakit. Jakarta: Kemenkes RI.
Notoatmodjo. (2012). Metodologi Penelitian Kesehatan. Jakarta: Rineka Cipta.

Rustiyanto, Ery. (2009). Etika Profesi Perekam Medis \& Informasi Kesehatan. Yogyakarta: Graha Ilmu.

Saryon dan Aggreani, Mekar Dewi. (2013). Tentang Metodologi Penelitian Kualitatif Dan Kuantitatif Dalam Bidang Kesehatan. Yogyakata: Nusa Medika.

Undang-Undang Republik Indonesia No. 44 Tahun 2009. Tentang Rumah Sakit. 